\title{
The Fourth Industrial Evolution and the Fight Against Carbon Leakage and the Issue of Climate Change
}

\author{
Đào Gia Phúc \\ University of Economics and Law, VNU-HCM, Ho Chi Minh City, Vietnam
}

\begin{abstract}
National climate measure or border carbon adjustment is one of the best solutions to combat carbon leakage, and the issue of climate change since international cooperation has not reached any significant movement in decades. However, the adoption of such measures can be faced with legal uncertainties under the legal framework of the World Trade Organization (WTO) with its principles of trade liberalizations. Particularly, border carbon adjustment might violate the market access, non-discrimination principles, disciplines of technical regulations, and the regulations on subsidies. This paper focuses on the legal hurdles of the issue and discusses a possible approach to enhancing the capacities of the domestic industries itself to offset the disadvantages of competitiveness especially within the fourth industrial evolution rather than strict measures imposing on imports that may violate the international trade law.
\end{abstract}

Keywords: the fourth industrial evolution, climate change, border carbon adjustment, carbon leakage, WTO law

According to Intergovernmental Panel on Climate Change (IPCC), greenhouse gas (GHG) emissions from 2000-2010 were even larger than in the previous three decades. As a result, the average global temperature rose by $0.85^{\circ} \mathrm{C}$ from 1880-2012 and the global sea level also rose by $19 \mathrm{~cm}$ (1901-2000) (IPCC, 2013). The impacts of climate changes are not only limited to extreme weather events (e.g. floods, drought, typhoons, etc.) but also to agricultural trade sectors, foods security, diseases, and extinctions of plants and animals (IPCC, 2013). Therefore, it undoubtedly needs to have significant contributions from lawmakers, policies, and international organizations if we wish to avoid irreversible damage with catastrophic consequences.

The connection between the international trade and the climate change is an undeniable and very complex issue. Every business activity conducts an environmental consequence, and the collective impact of those activities affects the climate of the whole planet. Especially, much of the world's energy needs which are likely mainly depend on fossil fuels, together with an increase in global population, will lead to a higher level of GHG emissions. In another hand, free trade can take part in the climate change mitigation's process by encouraging the development of climate-friendly technologies and the efficiency of resource use (Tîmbur, 2010). Moreover, the well-known environmental Kuznets curve (Franklin \& Ruth, 2012) (see Figure 1) has shown that the environmental degradation worsens as per capita GDP increases until the curve reaches a turning point, after which the environment improvement shall occur.

Corresponding author: Đào Gia Phúc, Ph.D. candidate, Transnational Doctoral Program for Leading Professionals in Asian Countries, Nagoya University, Japan, lecturer of Faculty of Economic Law, vice director of American Law Center, University of Economics and Law, VNU-HCM, Ho Chi Minh City, Vietnam; research fields: international economic law, international trade law. 


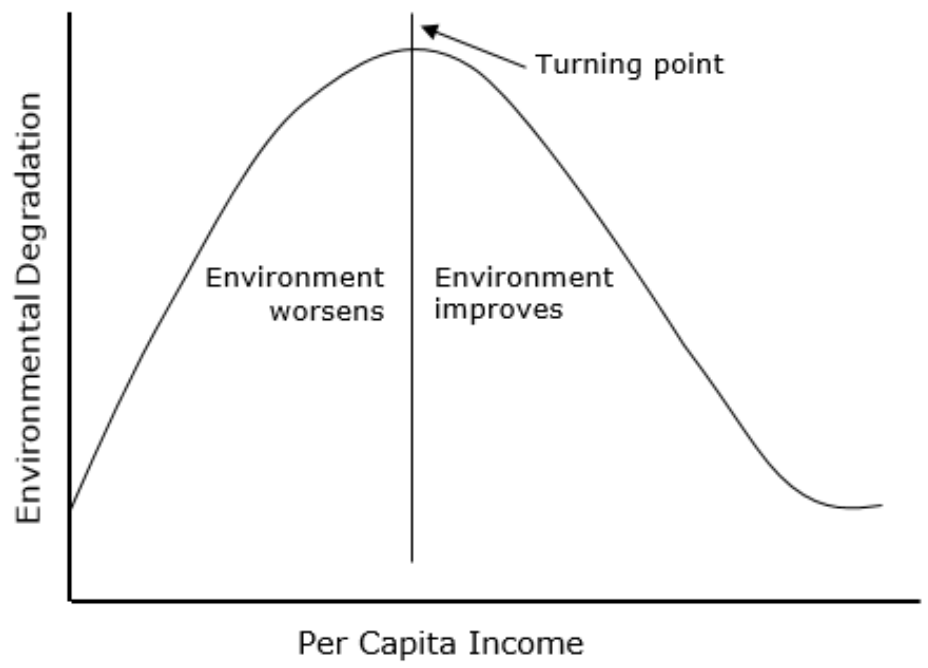

Figure 1. The environmental Kuznets curve. Source: http://alturi.com/kexsi.

Since the relationship between climate change and trade becomes obvious and no country can take effective action to control such issue alone, there is a demand for international collective action. States and regulators working in disciplines that have long been free-standing now have to engage with the realities of cross-regime coherence that can only be realized through collaborative action (World Bank, 2009; Stern \& Treasury, 2007).

As part of multilateral efforts to combat climate change, countries during the Rio and Kyoto UN Conferences on Environment \& Development agreed to set pollution control targets for developed countries while still leaving the developing countries with easier conditions for compliance. This is a great effort by the international community to limit the negative impact of pollution. However, the pollution targets for the production of particular goods and services of a particular country are not specified. Even within the 21st Annual Conference of Parties (COP 21, also known as 2015 Paris Climate Conference), the commitments of countries are still founded on a voluntary basis without any legally binding caps (Mahapatra \& Ratha, 2017). In addition, the levels of reduction between developed and developing countries vary considerably. These arrangements have led to unequal competition conditions between domestic and foreign producers. While countries with strict emissions reduction targets may be well intentioned, it is generally the case that domestic produces bear a significant portion of the emissions reduction costs. The unequal application of such policies between nations consequently incentivizes companies to relocate their carbon-intensive production to countries with no carbon or lax constraint regime to balance the competition condition. As a result, a strict climate policy in one country may, in fact, lead to an increase of GHG emissions in countries with low or no carbon emissions restrictions. The result of such inconsistent application of emissions reduction policies may lead to the fight against climate change being meaningless. This phenomenon has been called as "carbon leakage" (van Asselt \& Brewer, 2010, p. 42).

This issue can be overcome by also putting the price on emissions of foreign products through border adjustment measures. The measures could balance the playing field between domestic and foreign products in this context and help domestic industries be less hesitant to take part in national emissions reduction schemes. The foreign producers could also be encouraged to reduce the carbon footprint of their products for lower taxes and lax regulations from importing countries with strict emissions reduction regime. The logical consequence 
of the production of developing countries, which are major global GHG emitters and exporters of carbon-intensive products, is the transition to low-carbon economies comparable to those exist in developed countries such as EU, US, and Japan. In contrary, such measures may face critiques from developing countries since the difference in the level of developments could not lead to the same burden of climate change mitigation costs. The politic considerations may prevent developing countries to participate in climate change negotiations and trigger retaliation measures.

The application of "border carbon adjustments" (BCAs) not only faces with considerations in politics but also legal uncertainties in international trade law settings. The concept of restricting trade through imposing measures on carbon-intensive products has referred as BCAs (Weber, 2015, pp. 407-408). The measure can mainly be in forms of price based or non-price based restrictions or regulations including trade restriction on imports, international reverse allowances, carbon taxes, and emissions reduction related regulations. While restrictions and regulations on imports and exports are normal practices in international trade, BCAs themselves are not applied directly on products but rather on non-product-related processes and production methods (npr-PPMs) and might be suffered from the risk of being in violation with the legal framework of the World Trade Organization (WTO law).

\section{An Overview of Policy Options to Address Carbon Leakage}

There are a broad range of policy measures available that may be considered to address competitiveness and carbon leakage arising from the implementation of carbon reductions regime. These measures (Hourcade, Damailly, Neuhoff, \& Sato, 2014; Graichen et al., 2008; Reinaud, 2008; Houser, Bradley, Childs, Werksman, \& Heilmayr, 2008; Neuhoff et al., 2008) can be named as measures leveling costs upward through the conclusion of global or sectorial agreements and measures at the border implementing flexible adjustments.

\section{A Global Agreement for a Cost Adjustment of GHG Emissions}

A global climate agreement is undoubtedly the best solution to address the carbon leakage issue (van Asselt \& Brewer, 2010, p. 43). The imposition of similar carbon price levels or similarly stringent caps for all participating countries, as well as binding commitments of emissions reduction through a multilateral climate change agreement that is underpinned by each member nation's legislation could restrict disputes that may arise between countries and stem industries from relocating their production bases according to the differential of carbon price. In the long term, this could also help to attract investors looking for countries with a sturdy and predictable climate policy framework.

However, the feasibility of such an agreement requires huge incentives to persuade countries to participate (Colombier \& Neuhoff, 2008, p. 164). Such incentives raise the concern of sufficient financial assistance to convince developing countries (mostly emerging economies) and the ones who will pay for it. With the diverse developments of the top 10 carbon emitting countries accounting for two-thirds of global GHG emissions (including China, the US, India, Russia, Japan, Germany, South Korea, Canada, Iran, and the UK) (Nejat, Jomehzadeh, Taheri, Gohari, \& Abd. Majid, 2015), a scenario for those countries sitting down and reaching a consensus on an emissions reduction commitment may be impossible in the foreseeable future. On the side of developing countries, the question of how to balance the autonomy of national legislatures on one hand and the influence of supranational authorities to fiscal policy matter on the other continues to be controversial (Hufbauer \& Kim, 2010). 


\section{Flexible Adjustments Through Border Adjustments}

Instead of measures supporting domestic producers or efforts to conclude a global agreement, a state could address carbon leakage by imposing border adjustments that target imports and exports that originate from or are destined for countries that have no comparable GHG emissions reductions system. The key difference between this approach and the other two types of measures mentioned above is that adjusting GHG emissions costs at the border could provide a mechanism to immediately address the issue of carbon leakage ${ }^{1}$. Such BCAs include tariffs, taxes, quotas, subsidies, or technical regulations that can level GHG emissions costs both upward and downward. In other words, BCAs address the risk of carbon leakage by imposing trade restrictions on carbon-intensive imports and compensating emissions costs for domestic exporters. The proposal of a national climate policy with BCAs provisions has recently gained the support not only from policymakers but also from scholars in the field (van Asselt \& Brewer, 2010, p. 42) as a more feasible solution to offset carbon leakage than a multilateral approach.

\section{Measures Targeting Imports}

Trade restriction on imports. Being inspired by strict regulations in the Montreal Protocol ${ }^{2}$, which achieved the success of a ban on import of CFCs (chlorofluorocarbon) and CFC-related products with non-parties, some proposals suggested that the Kyoto Member States should apply embargoes to products from non-Kyoto countries or from countries that refuse to take part in the Kyoto process (Bhagwati \& Mavroidis, 2007, p. 300). However, unlike Montreal Protocol aiming to prevent certain harmful chemical substances (mainly used in some industries as refrigerants, solvents, foam blowing substances, aerosols, and fire extinguishers) from damaging ozone layer, the targets of Kyoto Protocol are the reduction of GHG emissions that are produced by most industries, thus impacting a broad range of products and human activities. Another approach of this type of measure is to put a ban on products manufactured using high emissions processes. This requires the importing countries to have details on the production process of imported products. Similar to requirements associated with genetically modified organisms (GMOs), the measure may face the challenge of traceability given the complex production chains of today (Cottier, Nartova, \& Bigdeli, 2009, p. 59).

International reverse allowances. International reserve allowances (IRAs) or emissions allowances on imports would be regulated under a cap-and-trade scheme ${ }^{3}$. Under this measure, in order to gain access to a specific market, a product would either originate from a country that has a program equivalent to the emissions control program in the destination country, or it would be required to submit allowances sufficient to cover the attributable GHG emissions. Such allowances might be acquired by purchasing carbon credits from an established emissions trading scheme on the market or from a special international reserve. Failure to submit such allowances would bar entry of imported products.

Border tax adjustments. A measure to address carbon leakage may also take the form of a price-based measure such as a duty, charge, or tax on carbon-intensive products on the release of GHG emissions into the

\footnotetext{
1 The analysis of energy-intensive sectors subject to carbon pricing points out that trade flows are the significant cause of emission leakage in the short term, whereas capital flows supplement in the mid to long term. See Dröge et al. "Tackling Leakage in a World of Unequal Carbon Prices".

${ }^{2}$ Montreal Protocol on Substances that Deplete the Ozone Layer, done at Montreal, September 16, 1987.

${ }^{3}$ A prime example of this type of measure is the proposal of the International Brotherhood of Electrical Workers and American Electric Power that IRAs should be included in the US climate change policy.
} 
atmosphere 4 . This type of "carbon tax" or border tax adjustment (BTA) which applies both to domestic and foreign products, is calculated according to the GHG emissions emitted by products during their manufacture. A BTA can thus be applied both to consumers and producers; however, many countries directly apply this "carbon tax" on consumers through a duty on fuel consumption (Tamiotti et al., 2009, p. 90).

Regulatory measures. A government can include in its climate change policy a set of standards or technical regulations relating to the GHG emissions generated during a product's use or the production process. Such measures, although intended to be applied equally to domestic and imported products, may still cause an adverse effect on the competitive condition in the market for imports. Failing to do so, the producers could be required to surrender allowances for the price differential between the cost of production and the carbon footprint to offset lower standards pertinent to imported goods, or otherwise have their products banned from entering the market ${ }^{5}$.

A standard could also be a labeling requirement indicating the carbon footprint of a product. The original idea of this measure is for consumers' preferences on low GHG emissions products, but in fact, carbon labeling requirements can be used to implement or facilitate an ETS (Emissions Trading Scheme) or carbon tax system ${ }^{6}$ (Hufbauer, Charnovitz, \& Kim, 2009, p. 68).

\section{Measures Targeting Export}

Besides measures targeting imports to ensure a level playing field in a country's domestic market, a government could also issue measures targeting exports to offset the competitive disadvantages of its products in foreign markets. The aim of such measures is to reduce the costs of production for exports, such as by imposing an export side border adjustment of charges incurred under an ETS. For instance, in the case of admission allowance rebates on exporters, a certain amount of emissions allowance issued under cap-and-trade system could be forgone. However, these types of measures may produce negative consequences for the effectiveness of the national GHG emissions reduction system ${ }^{7}$.

\section{The Legality of Border Carbon Adjustments Under WTO Law}

\section{Market Access and Non-discrimination Principles}

National climate measures in forms of BTAs and emissions allowances usually referred as price-based border adjustments (Regan, 2009, p. 104) which introduce a domestic carbon tax or domestic allowances requirements that apply to both domestic products and imported product usually based on the GHG emissions rate produced during the production and process methods (PPMs) of products. In particular, if imported products produced with low efficiency or carbon-intense energy sources, coal-produced steel, for example, would be, on an equal basis, taxed or treated at a higher, less favorable rate than domestic products made with more efficient production-methods or greener energy resources.

In general, GATT (General Agreement on Tariffs and Trade) provisions distinguish governmental

\footnotetext{
${ }^{4}$ A proposal to introduce BTAs of carbon taxes was made in Europe as early as at the beginning of the 1990s. They were linked to the efforts initiated by Finland to establish an EC-wide carbon tax system.

5 For an example, see U.S. House of Representatives, Committee on Energy and Commerce. (2008). Climate Change Legislation Design White Paper: Competitiveness Concerns/Engaging Developing Countries. Pp. 10-11.

6 There is a proposal of "carbon passport" indicating the carbon footprint of a product in order to provide necessary information to calculate the level of border adjustment in ETS or carbon tax system.

${ }^{7}$ A proposal from French government suggested that $2 \%$ of the total number of the GHG emissions allowances under the EU ETS third phrase would be rebated for EU exporters. See Holzer, Carbon-Related Border Adjustment and WTO Law, p. 53.
} 
measures into border measures and internal measures, and depending on how a price-based border adjustment will be classified, it will be allocated by a certain set of rules. As a result, the threshold issue of WTO laws compliance is to determine whether a price-based border adjustment at issue is a "border measure" or an "internal measure". Some scholars have argued that such adjustment especially in price-based form should fall within the broad allocation of Article III while the others consider them as "occulte taxes" which are defined in report of the GATT Working Party on Border Tax Adjustment but have not been decided yet by the members whether such taxes can be justified (Trachtman, 2016, pp. 6-10; Park, 2016, pp. 5-8). Therefore, at the current development of WTO law, this issue is still uncertain.

If the measure at issue is not considered as an internal tax in fact but rather being an import duty-a border measure, such measure could violate Article II of the GATT 1994 to the extent that they exceed the tariff bindings $^{8}$. On the other hand, if GHG price-based adjustments are tax adjustments on imports, there are two relevant principles that must be compliant. First, the National Treatment under Article III of the GATT 1994 which requires that imported products shall accord treatment "no less favorable" than "like" domestic products. And the second principle is the Most-Favored-Treatment under Article I of the GATT 1994".

The concept "like product" is not defined in the GATT, and it needs to be determined on a case-by-case basis. The Appellate Body in "Japan —Alcoholic Beverages II (1996)"10 clarified that the degree of likeness is considered by comparing products on: (1) products characteristics; (2) end uses; (3) consumer's tastes and habits; and (4) tariff classification. In "EC-Asbestos"11, the Appellate Body implied that likeness under Article III:4 of GATT is determined by, among other factors, the extent and nature of the competitive relationship between imported and domestic products. In a climate change context, the term "like product" may be controversial as in determining whether steel made with power from a coal plant and steel made with power from a hydropower plant are "like products". Thus, the key determination of likeness relies on the distinction between product characteristics and the way in which they are produced (PPMs). Traditional GATT case law did not seem to accept the possibility of applying PPMs as criteria to consider the likeness of products as illustrated by the unadopted "US-Tuna" 12 panel report. So, if products that are considered "like" based on traditional criteria of GATT case laws can be treated differently (and somehow discriminated) by a national climate measure based on their production and process methods, such measure could be deemed in violation of Article III and Article I of GATT.

\section{Article XX of the GATT 1994}

When a price-based adjustment violates Article I, II, or III, it may still be permitted if it satisfies the conditions set forth in Article XX of the GATT. The Appellate Body in "US-Gasoline"13 provides the

\footnotetext{
${ }^{8}$ Art II:1(b) of GATT: "The products described in Part I of the Schedule ... shall ... be exempt from ordinary customs duties in excess of those set forth and provided therein ...".

9 According to the language of Article I:1 of the GATT, in order to determine a measure both border and internal measures to be compliant with MFN principle, "any benefit" confers by a member to products destined in any countries shall be treat "no less favourable" than "like products" from other members immediately and unconditionally.

${ }^{10}$ Appellate Body report, "Japan—Taxes on Alcoholic Beverages", WT/DS8/AB/R, WT/DS10/AB/R, WT/DS11/AB/R, adopted November 1, 1996, para. 117.

11 Appellate Body report, "European Communities-Measures Affecting Asbestos and Asbestos Containing Products", WT/DS135/AB/R, adopted April 5, 2001, para. 93.

12 GATT panel report, "United States-Restrictions on Imports of Tuna" (US-Tuna), DS21/R, September 3, 1991, unadopted, BISD 29S/155, para. 155.

${ }_{13}$ Appellate Body report, "United States-Standards for Reformulated and Conventional Gasoline" (US-Gasoline), WT/DS2/AB/R, adopted May 20, 1996, p. 22.
} 
two-tier test to determine whether a violated measure can justify under Article XX. First, the measure at issue must fall within one of the exceptions from sub-paragraphs from (a) to (j). Second, that measure must also satisfy the chapeau of the article. Among exceptions listed in Article XX, the two paragraphs (b) and (g) could play an important role in justifying the violation of such national climate measure. Paragraph (b) allows exceptions for measures that are "necessary" to protect human, animal, or plant life, or health while paragraph (g) allows exceptions for measures relating to the conservation of exhaustible natural resources.

In order to determine whether the measure at issue is "necessary" to achieve a public policy goal in paragraph (b), the Appellate Body, firstly, in "Korea-Various Measures on Beef (2001)"14 developed a necessity test involving a "weighing and balancing" of the values at issue. Then in "Brazil-Retreated Tyres (2007)"15, the Appellate Body shifted to the existence of a material contribution of a measure to the achievement of its objectives. The existence of less-trade-restrictive alternatives thus plays an important role to justify a measure successfully under paragraph (b). This means that a WTO member challenging the legality of a GHG price-based adjustment against Article XX defense would have to prove that there were other less-trade-restrictive possibilities to combat the climate change other than the original measure ${ }^{16}$. Therefore, the main purpose of the measures must be defined by their impact in reducing global emissions rather than for their role in reducing competitiveness concerns for domestic industries. Many scholars argued that with this inference from paragraph (b), GHG climate measures that rebate the cost of a carbon tax on exports from countries without climate change regulations may fail the consistent test of the paragraph (Monjon \& Quirion, 2011).

Unlike paragraph (b), which allows for exceptions "necessary to protect human, animal or plant life or health", paragraph (g) applies to measures "relating to the conservation of exhaustible natural resources". Panel and Appellate Body have been clarified the term "exhaustible resources", so far, as tuna ${ }^{17}$, sea turtles ${ }^{18}$, dolphins $^{19}$, salmon and herring ${ }^{20}$, and clean $\operatorname{air}^{21}$. Some scholars believed that, in the climate change context, the levels of carbon and GHG in the atmosphere could also be viewed as an exhaustible natural resource like clean air in "US-Gasoline (1996)" (Condon, 2009). However, this issue is still unclear and it should be further clarified in future climate change-related WTO cases as well as be supported by multilateral environmental agreements. Another element that must be qualified in paragraph (g) relates to the term "relating to". This requirement asks for a close and real relationship of ends and means ${ }^{22}$ such as a close and genuine relationship

\footnotetext{
${ }^{14}$ See Appellate Body report, "Korea-Measures Affecting Imports of Fresh, Chilled and Frozen Beef", WT/DS161/AB/R, WT/DS169/AB/R, adopted January 10, 2001, para. 161-164.

${ }_{15}$ See Appellate Body report, "Brazil—Measures Affecting Imports of Retreaded Tyres", WT/DS332/AB/R, adopted December 3, 2007, para. 151 .

16 The Appellate Body at first required the country invoking the exception would have to prove the absence of alternatives, but then conclude that such country only needs to show the necessity of the measure. The burden of proof is then on the side of the complaining country. See Appellate Body report, "United States-Measures Affecting the Cross Border Supply of Gambling and Betting Services”, WT/DS285/AB/R, adopted April 20, 2005, para. 309.

${ }^{17}$ GATT panel report, "United States-Prohibition of Imports of Tuna and Tuna products from Canada", L/5198-29S/91, adopted February 22, 1982.

18 Appellate Body report, "United States_-Import Prohibition of Certain Shrimp and Shrimp Products" [US-Shrimp (1998)], WT/DS58/AB/R, adopted November 6, 1998.

19 GATT panel report, "US-Tuna", supra note 12.

${ }^{20}$ GATT panel report, "Canada-Measures Affecting Exports of Unprocessed Salmon and Herring”, L/6268-35S/98, adopted March 22, 1988.

${ }^{21}$ Appellate Body report, "United States—Standards for Reformulated and Conventional Gasoline" [US - Gasoline (1996)], WT/DS2/AB/R, adopted May 20, 1996.

22 Appellate Body report, "US-Shrimp" (1998), para. 128-131.
} 
between the structure of the GHG price-based adjustment and the carbon emissions reduction goals in the context of climate change. This clause also contains an unambiguous requirement that even-handed domestic policies are also undertaken to obtain the public policy objective but do not ask for an identical treatment of domestic and imported products (Condon, 2009, pp. 920-926). It is then uncertain whether a different treatment based on products' impact on climate change could qualify this requirement.

These exception provisions in paragraph (b) and (g) must be interpreted alongside the Chapeau of Article $\mathrm{XX}$, which requires that a measure must not be applied in a manner that constitutes "a means of arbitrary or unjustifiable discrimination" or "a disguised restriction on international trade". In climate change context, these good-faith criteria would require that the implementing country demonstrates its serious efforts to seek international agreement on climate change prior to enacting a GHG price-based adjustment ${ }^{23}$. From this point of view, some scholars believed that, in the case of an international agreement like the Kyoto Protocol, which sets emissions-reduction targets for certain period, it may lead to an outcome that parties have only met their goals at the end of the evaluation period. Then, whether it could be considered arbitrary or unjustified discrimination, or otherwise disguised restrictions on trade to impose a national climate measure against certain countries that have not committed GHG emissions targets and not others during this period is still an open question (Wiers, 2008).

\section{TBT Agreement}

For a national climate measure to fall within the application scope of the TBT (Technical Barriers to Trade) Agreement as a "technical regulation",24, it must: (1) lay down product characteristics; (2) be mandatory; and (3) apply to an identifiable product or group of products. The definition of a technical regulation in the first sentence of Annex 1.1 of the TBT Agreement indicates "product characteristics for products or related process and production methods" while in the last sentence of the article, measures that are concerned with "terminology, symbols, packaging, marking or labeling requirements as they apply to a product, process or production method" can be considered as technical regulations. In other words, a non-product-related national climate measure, prima facie, may not fall within the scope of application of TBT, since it requires the "related" element, but if such a measure is adopted in the form of a labeling requirement, it may be covered by the agreement. To date, the complained measures in "US-Tuna II (Mexico) (2012)"25 and "US-COOL $(2012), 26$ were labeling requirements relating to non-product-related PPMs. The United States, in both cases, did not question the scope of application of the TBT Agreement for these measures. Some commenters agreed that, in case the TBT Agreement does not regulate non-product-related national climate measures, such measures cannot be prohibited by the agreement and thus, would be examined under Article III and Article XI and may find justification under Article XX (Park, 2016, pp. 22-23).

The TBT Agreement encourages members to harmonize internal measures with international standards by providing that a technical regulation based on an existing international standard shall be deem consistent with

\footnotetext{
${ }^{23}$ The Appellate Body in "US-Shrimp" (1998) ruled the issue of good faith in relation to international efforts from US to address the environmental objective - turtle conservation in the context of the Chapeau leading to "unjustifiable discrimination". See Appellate Body report, "US-Shrimp", para. 168.

${ }^{24}$ See Annex 1.1 of TBT Agreement.

25 Appellate Body report, "United States-Measures Concerning the Importation, Marketing and Sale of Tuna and Tuna Product" (US-Tuna II), WT/DS381/AB/R, adopted May 16, 2012.

26 Appellate Body report, "United States-Certain Country of Origin Labelling (COOL) Requirements", WT/DS384/AB/R, adopted July 23, 2012.
} 
the TBT Agreement. This regulation in Article 2.4 is very helpful in the context of international cooperation and governance; however, there is no comprehensive definition of the term "international standards" within the agreement. The Appellate Body ruled the matter as a standard that is adopted by an international organization or body and made available to all WTO members in a non-discrimination manner ${ }^{27}$ without a requirement that such international standard must be adopted by consensus ${ }^{28}$. It remains unclear whether a climate change standard could be considered as an "international standard" especially standards developed by a group of WTO members which may not be appropriate for the development objectives of developing countries.

\section{Subsidies}

Article 1.1 of the SCM (Subsidies and Countervailing Measures) Agreement rules the term "subsidy" as a "financial contribution" by a "government or any public body" that confers a "benefit". Besides, a subsidy must be deemed "specific". In climate change context, a free allocation of GHG permits, for an example, may constitute a subsidy within the meaning of SCM Agreement. Because it can be a "financial contribution" in the form of a "revenue ... foregone" by the government, it brings the "benefit" to the "specific" companies or industry receiving an allocation. Support from the government for its domestic industry to combat climate change therefore could be considered a "subsidy" within the SCM Agreement. However, such measures prima facie are not prohibited; it depends on the content of the subsidy per se. If a subsidy is classified as a "prohibited subsidy" 29 , it is deemed specific and may be challenged by another member in a WTO dispute settlement mechanism. An "actionable subsidy",30, on the other hand, can only be challenged in a dispute settlement when the complaining member can show its "adverse effect" an importing member can also use a unilateral solution by imposing countervailing measures when its domestic industry has suffered from injury by those subsidies.

\section{Conclusions: A Possible Approach to Address Carbon Leakage Through the Active Participation of Domestic Industries}

Carbon leakage, competitive concerns are main drivers that have led countries to consider the adoption of national climate measures. Such measures can have an effect on international trade and thus violating WTO rules. Using carbon leakage as the rationale for a national climate measure can support characterizing the measures as an environmental measure-mitigating climate change. However, with the drivers from competitiveness concerns, it will be more likely an economic measure with the protection of jobs and secure of economic development by leveling the playing field states between strict and less climate standard.

It should also be noted that national measures to address the competitiveness loss can only arrive at limited findings as it deals only with the price element of competitiveness. Whereas carbon policy is only one part of the broader industry picture, there are still many non-price elements influencing companies' decisions on production levels and investment. Looking at production and investment decisions only through the lens of climate policy certainly, it maintains the negative image of asymmetric action and could oversimplify the picture on industry's location choices. Studies on competitiveness under asymmetric carbon constraints do not

\footnotetext{
${ }^{27}$ Appellate Body report, "US-Tuna II”, para. 374-375.

28 Appellate Body report, "European Communities—Trade Description of Sardines”, WT/DS231/AB/R, adopted September 26, 2002, para. 222.

${ }^{29}$ Part II of the SCM Agreement.

${ }^{30}$ Part III of the SCM Agreement.

31 Article 5 of the SCM Agreement.
} 
consider the possible positive effects of ETS on companies' competitiveness if they are the first to develop low-carbon technologies (i.e. the first-mover advantage). Delivering ambitious targets will require actions across a range of playing fields: rapidly conducting and implementing new approaches to promoting investment flows towards low-carbon developmental production and removing barriers to trade and investment to support and facilitate large-scale distribution of climate-friendly goods; services and technologies are just two. Gaining political support for these kinds of actions may be challenging, even impossible, without a further eyesight of the potential benefits rather than costs of the low-carbon transition. Investments in energy-efficient technologies will help improve the productivity of companies and strengthen their competitive position and are expected to become more important as the global price of energy increases. Another aspect of competitiveness and leakage that is not studied enough in the literature is the possibility for non-participating countries to benefit from technological developments taking place in those countries with ETS. In the longer run, these so-called spillover effects may help non-participating countries reduce their GHG emissions-not to mention making their industries more efficient and competitive.

Finally, it is important to remember that there is a discrepancy between how policymakers look at competitiveness and how companies themselves see it. Growth in investment in an emerging country may enhance the competitiveness of firms in a developed country that established plants in the country, even though from a European perspective, it is perceived as a loss of competitiveness. Further, plant closures sometimes result from a decision to focus activity on higher value-added parts of the production chain - an odd proposition regarding profitability, even if the result is increased imports of energy-intensive goods, sometimes akin to carbon leakage.

\section{References}

Ahmed, K., \& Long, W. (2013). Climate change and trade policy: From legal complications to time factor. Journal of International Trade Law \& Policy, 12(3), 258-271.

Alabi, S. A. (2012). Using litigation to enforce climate obligations under domestic and international laws. Carbon \& Climate Law Review: CCLR, 6(3), 209-220.

Belis, D., Joffe, P., Kerremans, B., \& Qi, Y. (2015). China, the United States and the European Union: Multiple bilateralism and prospects for a new climate change diplomacy. Carbon \& Climate Law Review: CCLR, 9(3), 203-218.

Bhagwati, J., \& Mavroidis, P. C. (2007). Is action against US exports for failure to sign Kyoto Protocol WTO-legal? World Trade Review, 6(2), 299-310.

Brenton, A. (2013). “Great powers” in climate politics. Climate Policy, 13(5), 541-546.

Bretschger, L. (2013). Climate policy and equity principles: Fair burden sharing in a dynamic world. Environment and Development Economics, 18(5), 517-536.

Casier, L., Fraser, R., Halle, M., \& Wolfe, R. (2014). Shining a light on fossil fuel subsidies at the WTO: How NGOs can contribute to WTO notification and surveillance. World Trade Review, 13(4), 603-632.

Charnovitz, S. (2010). Trade and climate change: A report by the United Nations Environment Programme and the World Trade Organization. World Trade Review, 9(1), 273-281.

Colombier, M., \& Neuhoff, K. (2008). Sectoral emission agreements - Can they address leakage? Environmental Policy and Law, $38(3), 161-166$.

Condon, B. J. (2009). Climate change and unresolved issues in WTO law. Journal of International Economic Law, 12(4), 895-926.

Corvaglia, M. A. (2014). South-South technology transfer addressing climate change and its (missing) international regulatory framework. Carbon \& Climate Law Review: CCLR, 8(2), 125-137.

Cottier, T., Nartova, O., \& Bigdeli, S. Z. (2009). International trade regulation and the mitigation of climate change: World trade forum. Cambridge: Cambridge University Press.

de Sépibus, J., \& Holzer, K. (2014). The UNFCCC at a crossroads: Can increased involvement of business and industry help rescue the multilateral climate regime? Carbon \& Climate Law Review: CCLR, 8(1), 23-34. 
Deane, F. J. (2014). Emissions trading and the GATS financial services provisions: A case study of the Australian carbon pricing mechanism. Journal of International Trade Law \& Policy, 13(1), 44-66.

Eichner, T., \& Pethig, R. (2015). Unilateral climate policy with production-based and consumption-based carbon emission taxes. Environmental and Resource Economics, 61(2), 141-163.

Frankel, J. (2005). Climate and trade: Links between the Kyoto Protocol and WTO. Environment, 47(7), 8-19.

Franklin, R. S., \& Ruth, M. (2012). Growing up and cleaning up: The environmental Kuznets curve redux. Applied Geography, 32(1), 29-39.

Graichen, V., Schumacher, K., Matthes, F. C., Mohr, L., Duscha, V., Schleich, J., \& Diekmann, J. (2008). Impacts of the EU Emissions Trading Scheme on the industrial competitiveness in Germany. Berlin: German Federal Environment Agency.

Haites, E., Yamin, F., \& Höhne, N. (2014). Possible elements of a 2015 agreement to address climate change. Carbon \& Climate Law Review: CCLR, 8(1), 3-12.

Hallding, K., J“risoo, M., Carson, M., \& Atteridge, A. (2013). Rising powers: The evolving role of BASIC countries. Climate Policy, 13(5), 608-631.

Hansen, J., Kharecha, P., Sato, M., Masson-Delmotte, V., Ackerman, F., Beerling, D. J., ... Zachos, J. C. (2013). Assessing "dangerous climate change": Required reduction of carbon emissions to protect young people, future generations and nature. PLoS One, 8(12), e81648.

Holzer, K. (2010). Proposals on carbon-related border adjustments: Prospects for WTO compliance. Carbon \& Climate Law Review: CCLR, 4(1), 51-64.

Holzer, K., \& Shariff, N. (2012). The inclusion of border carbon adjustments in preferential trade agreements: Policy implications. Carbon \& Climate Law Review: CCLR, 6(3), 246-260.

Hourcade, J.-C., Damailly, D., Neuhoff, K., \& Sato, M. (2014). Differentiation and dynamics of EU ETS industrial competitiveness impacts: Final report. Retrieved from http://climatestrategies.org/wp-content/uploads/2007/12/1-climate strategies-competitiveness-final-report-140108.pdf

Houser, T., Bradley, R., Childs, B., Werksman, J., \& Heilmayr, R. (2008). Leveling the carbon playing field: International competition and US climate policy design. Retrieved from http://pdf.wri.org/leveling_the_carbon_playing_field.pdf

Hufbauer, G. C., \& Kim, J. (2010). Climate change and trade: Searching for ways to avoid a train wreck. Proceedings from TAIT Second Conference "Climate Change, Trade and Competitiveness: Issues for the WTO”. June 16-18, Geneva.

Hufbauer, G. C., Charnovitz, S., \& Kim, J. (2009). Global warming and the world trading system. Washington, D.C.: Peterson Institute for International Economics.

IPCC. (2013). Fifth assessment report-Climate change 2013: The physical science basis. Retrieved from https://www.ipcc.ch/ report/ar5/wg1/

IPCC. (2014). Climate change 2014: Synthesis report. Retrieved from http://www.ipcc.ch/pdf/assessment-report/ar5/syr/SYR_ AR5_FINAL_full_wcover.pdf

Kaufmann, C., \& Weber, R. H. (2011). Carbon-Related border tax adjustment: Mitigating climate change or restricting international trade? World Trade Review, 10(4), 497-525.

Kent, A. (2014). Implementing the principle of policy integration: Institutional interplay and the role of international organizations. International Environmental Agreements: Politics, Law and Economics, 14(3), 203-224.

Kienast, A. N. (2015). Consensus behind action: The fate of the Paris Agreement in the United States of America. Carbon \& Climate Law Review: CCLR, 9(4), 314-327.

Ladly, S. D. (2012). Border carbon adjustments, WTO-law and the principle of common but differentiated responsibilities. International Environmental Agreements: Politics, Law and Economics, 12(1), 63-84.

Leal-Arcas, R. (2013). Climate change mitigation from the bottom up: Using preferential trade agreements to promote climate change mitigation. Carbon \& Climate Law Review: CCLR, 7(1), 34-42.

Mahapatra, S. K., \& Ratha, K. C. (2017). Paris climate accord: Miles to go. Journal of International Development, 29(1), 147-154.

Matsushita, M., Schoenbaum, T. J., Mavroidis, P. C., \& Hahn, M. (2015). The World Trade Organization: Law, practice, and policy. Oxford University Press.

Mattoo, A., Subramanian, A., van der Mensbrugghe, D., \& He, J. (2013). Trade effects of alternative carbon border-tax schemes. Review of World Economics, 149(3), 587-609.

Messerlin, P. A. (2012). Climate and trade policies: From mutual destruction to mutual support. World Trade Review, 11(1), 53-80. 
Meyer, T. (2014). From contract to legislation: The logic of modern international lawmaking. Chicago Journal of International Law, 14(2), 559-624.

Moïsé, E., \& Steenblik, R. (2011). Trade-Related measures based on processes and production methods in the context of climate-change mitigation. OECD Trade and Environment Working Papers. Paris: OECD Publishing.

Monjon, S., \& Quirion, P. (2011). A border adjustment for the EU ETS: Reconciling WTO rules and capacity to tackle carbon leakage. Climate Policy, 11(5), 1212-1225.

Moomaw, W. (2015). Will the Paris climate accord and future climate treaties be a vision or a roadmap? The Fletcher Forum of World Affairs, 39(2), 41-48.

Nejat, P., Jomehzadeh, F., Taheri, M. M., Gohari, M., \& Abd. Majid, M. Z. (2015). A global review of energy consumption, CO ${ }^{2}$ emissions and policy in the residential sector (with an overview of the top ten $\mathrm{CO}^{2}$ emitting countries. Renewable and Sustainable Energy Reviews, 43, 843-862.

Neuhoff, K., Matthes, F. C., Betz, R., Dröge, S., Johnston, A., Kudelko, M., ... Suwala, W. (2008). The role of auctions for emissions trading. Retrieved from http://climatestrategies.org/wp-content/uploads/2008/10/role-of-auctions-09-oct-08final. pdf

Park, D.-Y. (2016). Legal issues on climate change and international trade law. Korea: Springer.

Perrone, N. M. (2016). The international investment regime after the global crisis of neoliberalism: Rupture or continuity? Indiana Journal of Global Legal Studies, 23(2), 603-627.

Regan, D. (2009). How to think about PPMs (and climate change). In T. Cottier, O. Nartova, and S. Z. Bigdeli (Eds.), International trade regulation and the mitigation of climate change: World trade forum (pp. 97-123). Cambridge: Cambridge University Press.

Reinaud, J. (2008). Issues behind competitiveness and carbon leakage: Focus on heavy industry. Paris: IEA. Retrieved from https://www.iea.org/publications/freepublications/publication/Competitiveness_and_Carbon_Leakage.pdf

Lennon, E., Lyman, E., Meltzer, J., Redick, T. P., \& Smith, J. (2013). International environmental law. The International Lawyer, $47(4), 435-451$.

Shadikhodjaev, S. (2013). First WTO judicial review of climate change subsidy issues. The American Journal of International Law, 107(4), 864-878.

Shadikhodjaev, S. (2015). Renewable energy and government support: Time to "green" the SCM agreement? World Trade Review, 14(3), 479-506.

Sterk, W., \& Hermwille, L. (2013). Does the climate regime need new types of mitigation commitments? Carbon \& Climate Law Review: CCLR, 7(4), 270-282.

Stern, N. H., \& Treasury, G. B. (2007). The economics of climate change: The stern review. Cambridge: Cambridge University Press.

Stewart, R. B., Oppenheimer, M., \& Rudyk, B. (2013). A new strategy for global climate protection. Climatic Change, 120(1-2), $1-12$.

Tamiotti, L., Teh, R., Kulaçoğlu, V., Olhoff, A., Simmons, B., \& Abaza, H. (2009). Trade and climate change: A Report by the United Nations Environment Programme and the World Trade Organization. Retrieved from https://www.wto.org/english/ res_e/booksp_e/trade_climate_change_e.pdf

Tîmbur, M. (2010). International trade development-Risks for the environment? Economy Transdisciplinarity Cognition, 13(2), $6-22$.

Trachtman, J. P. (2016). WTO law constraints on border tax adjustment and tax credit mechanisms to reduce the competitive effects of carbon taxes. Retrieved from http://www.rff.org/files/document/file/RFF-DP-16-03.pdf

van Asselt, H., \& Brewer, T. (2010). Addressing competitiveness and leakage concerns in climate policy: An analysis of border adjustment measures in the US and the EU. Energy Policy, 38(1), 42-51.

Vihma, A., \& Kulovesi, K. (2013). Can attention to the process improve the efficiency of the UNFCCC negotiations? Carbon \& Climate Law Review: CCLR, 7(4), 242-251.

Viral, A. V. (2016). Environmental disputes in investor-state arbitration-A need for change. Environmental Policy and Law, $46(2), 133-136$.

Weber, R. H. (2015). Border tax adjustment—Legal perspective. Climatic Change, 133(3), 407-417.

Wiers, J. (2008). French ideas on climate and trade policies. Carbon and Climate Law Review, 2(1), 18-32.

Wong, P. (2015). From Copenhagen to Paris: Climate change and the limits of rationality, multilateralism, and leadership. The Brown Journal of World Affairs, 21(2), 268-283.

World Bank. (2009). Trade and climate change. In World development report 2010 (pp. 251-255). Washington, D.C.: World Bank Group. 